\title{
An Overview of Commodity Tax Reform in Southern Africa
}

\section{Z Robinson}

Department of Economics, University of Pretoria

\section{ABSTRACT}

Various studies have emphasised the trade and/or revenue implications of free trade. The purpose of this study is to investigate future tax implications of further economic integration. Additional considerations are whether tax competition can become an issue and whether it can be used to the benefit of all SADC members. An integrated approach was done of what is needed in terms of commodity taxation to reach a workable long-term solution. This article analyses experiences in the developing world with reference to lessons learned from developed regions. The first section provides a theoretical background, analysing the meaning of commodity tax. The second section emphasises the importance of fiscal decentralisation in federations and the SADC and the third investigates the character of and changes in commodity taxation that could occur in the future.

JEL H20

\section{INTRODUCTION}

The World Bank (1991) has expressed concern about tax competition and harmonisation in developing countries. This specifically includes competitive responses from other countries to incentives (tax holidays, accelerated depreciation, tax credits, and favourable resource royalties designed to attract foreign capital) used in developing countries. Unexplained phenomena relate to the effectiveness of these incentives to attract foreign capital and trade as well as the side effects of these incentives, e.g. tax discrimination, to induce or limit growth. The need for developing countries to harmonise taxes among themselves through multilateral and bilateral negotiations is therefore, again emphasised. Apart from finding sensible explanations for problematic tax practices, a continuous attempt is also made to find long-term workable solutions. The emphasis falls on Southern Africa, that is, the Southern African Development Community (SADC).

An African renewal has been postponed for many years. With the advent of the 
new millennium, President Mbeki of South Africa referred to this renewal as an "African Renaissance". The Millenium Partnership for the African Recovery Programme (MAP, 2001) led by Mbeki, Obasanjo of Nigeria and Boutefilka of Algeria, and the OMEGA Plan (OMEGA, 2001) proposed by President Wade of Senegal, can therefore be seen as a welcome change to previous efforts. At this special summit meeting of the heads of state and government in March 2001, the need to make provision for a new streamlined structure for the SADC in order to speed up its economic integration and cope better with the crisis in the region (e.g. the war in the DRC), was also recognised. Some of the proposed changes sought to create legal structures that would adjudicate issues of trade and economics that would not suit the interests of individual members. The aim of the reform process is to address the fears of smaller economies and to accommodate their aspirations and interests. The World Bank (2000: 34) points out that both "winners and losers (and more of the former than the latter)" should be recognised as the first step, although the persuasion of the winners to forgo some of their gains to compensate "influential losers who could otherwise stymie the process" should form part of trade and investment reform.

Although the SADC has gone beyond the initial stages of an FTA, tax competition and coordination problems as such have not yet surfaced. The possibility of a higher degree of economic integration may yet expose these in future. At the same time the formulation of macroeconomic convergence criteria for this region has become essential and this should be dealt with within the confinements of certain tax restrictions. The emphasis in this article is not specifically on trade or the revenue implications of free trade because various studies have already been conducted in this area. The purpose here is to take the lead and investigate the future tax implications of further integration. An additional consideration is whether the current situation can be used to the benefit of all SADC members. The idea is to form an integrated approach of what is needed in terms of commodity taxation to reach a workable long-term solution in terms of macroeconomic stability.

This article attempts to analyse experiences in the developing world with crossreferences to lessons that can be learned from developed regions. In this context, the first section analysis the meaning of commodity tax competition and therefore provides a theoretical background. A short background study of fiscal decentralisation is then provided and hence also the institutional character of the more "developed" federations in the developing world, namely Argentina, Brazil and India in comparison with the SADC. Deeper integration means increased exposure to the consequences of the removal of barriers to trade and factor movements and the experiences of selected federations can provide useful lessons. Argentina, however, is a unique case study, and is included because of its successes with institutional reform during the 1980s and 
1990s. On the downside, it is also included to show the effects of fiscal insustainability on macroeconomic stability ${ }^{1}$. The second section emphasises the importance of fiscal decentralisation in federations and the SADC. The third section emphasises the current character of and changes in commodity taxation that could occur in the future. The last section attempts to give an overview with some conclusions and recommendations.

If not otherwise mentioned, data and statistical resources utilised in the article are mainly from the Finance and Investment Sector Coordinating Unit (FISCU), the International Monetary Fund (IMF), the National Treasury of South Africa (NTSA), PriceWaterhouseCoopers (PwC), and the World Bank (WB). Various problems arise when one tries to analyse data from developing countries. In the case of African studies, Burkett, Humblet and Putterman (1999) state that the main problem is the unreliable nature of the available data. Different variables may be recorded for the same observation in different editions of the same source. The IMF (1998) warns that the results obtained by using data should be interpreted with caution. Before proceeding, it is therefore important to shed some light on the international status of developing countries in terms of taxation.

\section{COMMODITY TAXES AGAINST THE BACKDROP OF TAX COMPETITION}

Commodity taxation is investigated within a tax competition context by various authors. This type of analysis is especially applicable within a process of economic integration, e.g. in a common market or economic union, and a federation. Different commodity tax rates across borders create distortions that in turn induce spillovers or externalities such as cross-border shopping. The most familiar types of commodity taxes are the single-stage retail or general sales tax (RST/GST) and the multi-stage or broad-based value-added tax (VAT). The main difference between the two entails different methods of collection, with RST on a suspensive system and VAT on a repayment system; and the tax base that is being taxed also differs.

With VAT the onus is always on traders to convince the tax authorities that their claims for refunds on their inputs are justified, whereas under RST there are no such claims (the tax is levied only once at the final destination or on imports). The claims for refunds or the tax liability can be computed via subtraction, addition or tax credits (invoice method). Detailed records of purchases as well as sales have to be kept under a VAT mechanism but not under RST. Administrative difficulties may therefore occur more readily with VAT, but it is also normally implemented to curb tax evasion and corruption. VAT is also 
introduced for minimising "tax-on-tax” for which RST/GST is criticised.

\subsection{Mintz and Tulkens (1986)}

Mintz and Tulkens (1986: 135) were the first to investigate commodity tax competition between independent fiscal authorities. A two-region economy (high-tax and low-tax) where an origin-based commodity tax ${ }^{2}$ is levied by each region, is investigated. The tax is levied on a private good to finance a local public service. The Nash equilibrium of these tax rates is analysed whilst all other private goods are untaxed. A single region's market and fiscal decisions as functions of the region's characteristics as well as of its environment, is investigated.

The analysis is extended in order to consider simultaneous decisions made by the two regions. A so-called regional market equilibrium (RME) and interregional market equilibrium (NCFE) are included in the model. In these two cases, the equilibrium is fully efficient. The main reason for this is that transport costs are so high that no cross-border shopping occurs, either in equilibrium or in response to small tax changes. In these cases, none of the interregional externalities described previously appear. Wilson (1999) argues that it is difficult to describe these cases as "tax competition", because governments are not really competing over the tax base. Not all theorists on tax competition, however, share this view.

There is a two-person game and the players are local governments. The strategies are local taxes and expenditure levels, and the payoffs are the regional welfare function. Nash equilibrium is established in this two-person game in which there is collusion, i.e. a non-cooperative or competitive situation. This is referred to as a non-cooperative fiscal equilibrium (NCFE). A NCFE amongst two regions that choose optimal tax rates and public services production may not always exist due to a significant change in the fiscal or tax reaction functions. This means that a switch from one type of regime to another could occur. Differences in the regions' government size, as well as tax levels can therefore arise from strategic behaviour and not only from differences in tastes and endowments. In the absence of interregional public service spillovers, the inefficiency of a NCFE thus arises from two types of externalities, viz.:

(a) Negative private consumption effects (terms-of-trade effects) that occur when an increase in a region's tax affects the private good purchases of the other jurisdiction's residents; and

(b) Positive public consumption effects that occurs when an increase in one region's tax, increases the tax base of the other region (see also Bucovetsky 1995: 362). 
Emphasis is placed on the fact that tax competition is inefficient under the origin (source) principle in both regions and that cooperative policy measures may become essential in improving the outcome of the NCFE, in short Nash equilibrium.

\subsection{Kanbur and Keen (1993)}

In Kanbur and Keen's spatial model of cross-border shopping (1993: 877), it is argued that unrestricted tax competition (open borders) can take place between small and large regions (countries). The following assumptions are utilised:

(a) There is a partial-equilibrium model of two countries (home and host) and a single taxed good;

(b) The population is distributed uniformly in each country, but the two populations may differ in size;

(c) Commodity taxes are levied on a destination basis ${ }^{3}$, and there are no barriers to the entry or exit points of new stores; and

(d) The individual has two decisions to make when buying a commodity, viz. to buy in the home country or to travel to the host country with transportation costs involved.

A pay-off matrix can be utilised to show the results of the different game situations. In this case, the matrix (Table 1) describes unrestricted tax competition as a "prisoners' dilemma". Prisoners' dilemma is a famous case in game theory literature. Although the analysis is given in terms of commodities (cross-border shopping), the same analysis can be applied to mobile capital (Hallerberg, 1996).

Table 1 Prisoner's dilemma facing two regions on tax policy

\begin{tabular}{||c|c|c||}
\hline \multicolumn{1}{|c|}{$\begin{array}{c}\text { Region } \\
\text { Region a }\end{array}$} & $\begin{array}{c}\text { Confess (compete in } \\
\text { taxes) }\end{array}$ & $\begin{array}{c}\text { Deny (no tax } \\
\text { competition) }\end{array}$ \\
\hline Compete in taxes & $3,3^{1}$ & 6,0 \\
\hline $\begin{array}{l}\text { No tax } \\
\text { competition }\end{array}$ & 0,6 & 2,2 \\
\hline
\end{tabular}

Note: 1 These values $(\mathrm{x}, \mathrm{y})$ represent pay-offs in terms of ordinal utility between $\mathrm{A}$ and $\mathrm{B}$ (the higher the values, the better the pay-offs).

In Table 1 it is shown that Nash-equilibrium $(3,3)$ is reached where both regions $\mathrm{A}$ and $\mathrm{B}$ both compete in taxes. When small and large regions compete in 
taxes, both behave in a Nash manner. This means that each region chooses its own tax rate to maximise its tax revenue while assuming a fixed tax rate by the other region, bearing in mind the impact on cross-border shopping. In this equilibrium situation the small region (size relating to the number of residents) undercuts the large region because the small region's tax rate (t) is below the large region's tax rate (T), i.e. $\mathrm{t}<\mathrm{T}$. This point, however, is Pareto-inefficient. When neither region competes in taxes, i.e. tax competition is restricted (by closed borders), joint tax revenues are reduced or minimal, with larger regions suffering a revenue loss (if the difference in size is sufficiently great) and the small regions normally gaining revenue.

Cnossen (1990: 476) argues that the potential revenue loss with cross-border shopping may be particularly injurious to smaller regions because these regions are normally rate-takers and not rate-setters as is the case in larger regions. Smaller regions normally tend to set rates lower to increase the volume of their sales. It is therefore undesirable to set a uniform tax rate somewhere between $t$ and $\mathrm{T}$ because this will always harm small regions, relative to the Nashequilibrium. It will, however, be beneficial to the large country (relative to the Nash equilibrium or unrestricted tax competition) if harmonisation takes place at rate $\mathrm{T}$ (rate-setter); but harmful if harmonisation takes place at rate t (ratetaker). Setting a minimum tax rate somewhere between $t$ and $\mathrm{T}$, will lead to the small region setting the minimum rate, still undercutting the large region. In this case both regions will set their tax rates higher at point $(2,2)$ and, therefore, revenue will increase in both the large and small regions. This point is thus Pareto-efficient because there is no other strategy choice that makes both players better off. Tax competition is therefore inefficient. Kanbur and Keen (1993: 889) offer two criteria to determine the optimality of coordination, viz. Pareto-efficiency and joint product or revenue maximisation. In the latter instance it is possible to make compensating transfers between the revenuelosing and revenue-gaining regions.

In the next section a short background study of fiscal decentralisation is provided and hence also the institutional character of the more "developed" federations in the developing world, namely Argentina, Brazil and India in comparison with the SADC.

\section{FISCAL DECENTRALISATION WITHIN FEDERATIONS AND THE SADC}

Argentina and Brazil, two of the largest federations and democracies in Latin America, have been chosen as examples. Together with sub-Saharan Africa (SSA), Latin America has the highest number of regional groupings in the 
developing world, often with overlapping membership and objectives ranging from limited cooperation in specific areas to full-fledged economic integration. Furthermore, Latin America has had significant tax reforms since the 1980s with substantial growth in FDI inflows during the 1990s as well as macroeconomic instabilities.

India, the largest democracy in the world, has a long history in federal finance and has been chosen as the representative of the Asian region. South, East and South-East Asia are currently attracting most of the FDI inflows to developing countries worldwide (UNCTAD, 2000) with China at the forefront. The region becomes even more interesting if one takes the effects of the financial crisis of 1997 into account, but at the same time realising the advantages of global production networks and attracting most of the parts and components trade worldwide (see World Bank, 2000: 66). Africa, which is still struggling to become a major market player, can therefore learn from these and other experiences which are also unique in terms of sub-national commodity taxation in Argentina, Brazil and India. In the following sections, fiscal decentralisation which is prominent in the three federations, will be discussed and where possible compared with the SADC. Although fiscal decentralisation is not yet relevant to the SADC which still has a long way to go before being transformed into a common market or economic union, it lays a foundation and provides a summary of what these economies could become together or individually.

Figure 1 provides a summary of the fiscal decentralisation features in the federations in question and those members of the SADC, which possess actual components of decentralisation. The table provides only a glimpse at the degree of fiscal decentralisation and further discussions should shed some light on the different countries' tax and expenditure legislation.

Latin America has had a long tradition of centralisation, which dates back to the period of colonial administration. After the independence movement, centralised fiscal structures remained in place, partly because of colonial inheritance, and partly because of the need for countries to keep distant provinces under one power. Even today, when compared with the industrialised world, the region as a whole remains highly centralised. While sub-national levels of government are responsible for over 35 per cent of total government expenditure in industrialised countries, on average, in Latin America the corresponding figure is less than 15 per cent (Stein, 1998). The latter, however, does not refer to the federations within Latin America (Fig 1). Although the region remains highly centralised, the tendency towards decentralisation is quite strong. 


\section{Figure 1 The composition of sub-national shares in selected federations} and the SADC
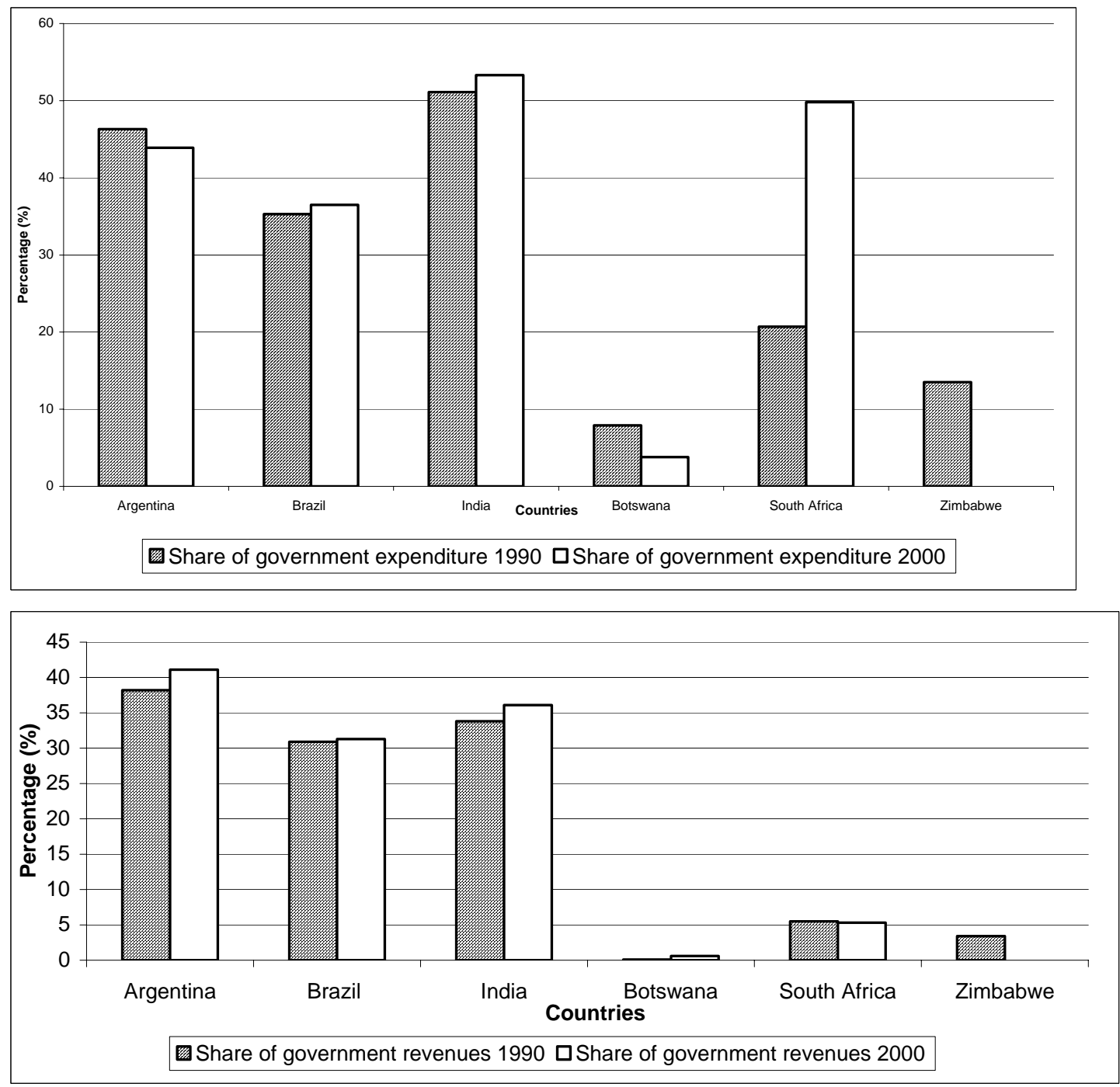

Source: IMF, 2002; See also Table A.1

In Latin America, revenues were traditionally decentralised before expenditure responsibilities, and national governments therefore had to maintain spending levels with a smaller resource base resulting in large deficits. For instance, Argentina's subnational governments' share of total governments expenditure declined from 46,3 per cent in 1990 to 43,9 per cent in 2000 while the opposite happened in government revenue. The national government's share has therefore declined even further in terms of revenues. Separate tax and spending powers have allowed subnational governments to incur only a fraction of the political and financial costs of their expenditures, especially when most local resources are funded from a common national pool of tax revenues creating a commons problem. Subnational governments have controlled substantial resources (e.g. the subnational VAT in Brazil), and in some cases have adopted revenues from these resources as their "own". Both national government and local governments levy limited forms of VAT but the state VAT is by far the 
most important of the three and it may therefore be difficult to find a solution to this problem. Although Brazil has gone a long way in the process of devolving revenue sources and expenditure functions to subnational governments and granting significant autonomy in policy making, local revenue mobilisation has hardly been encouraged by the country's system of intergovernmental transfers. A significant vertical fiscal imbalance has arisen in the Latin American region typically because more expenditure responsibilities have been assigned to local governments with limited own revenues.

The vertical fiscal imbalance has been greater than that in industrialised countries with an average of 42 per cent for OECD members compared to 52 per cent in Latin America. The vertical imbalance also seems to vary significantly between different countries in Latin America, and among decentralised countries the difference between Latin America and the OECD seems to be even greater. This suggests that finding a suitable tax base to assign to subnational governments is more difficult in the case of developing countries (Stein 1998: 105). The high degree of vertical imbalance in decentralised countries in the region creates the possibility of a commons problem, in particular when combined with highly discretionary transfer systems, or a large degree of borrowing autonomy. For instance, central bank bailouts to state banks that are "too big to fail" have been important in some Brazilian states, such as São Paulo and Rio de Janeiro. These tendencies can also be compared with tendencies in Asian economies.

The fiscal systems of East Asian economies have traditionally been highly centralised. In India, states have been granted substantial powers to tax and spend but these powers have not been properly implemented. Central government has maintained control over substantial resources and the states have had to cope with financing large spending functions with limited resources. However, this unitary behaviour appears to be changing gradually with a process of adjustment for states with high deficits and debt. This trend can be partly observed in an increasing tendency in both expenditure and revenue shares of subnational governments. Subnational shares have increased in terms of government expenditure (from 51,1 per cent in 1990 to 53,3 per cent in 2000) and with a greater but not significant amount in terms of revenues (from 33,8 per cent in 1990 to 36,1 per cent in 2000).

An overall summary of fiscal decentralisation in developing and developed countries provides insightful reading. Subnational expenditures comprise a small share of government expenditures (the median for developing countries is about 14 per cent), except in industrialised countries (the median is about 34 per cent) and large federations such as Argentina, Brazil, Canada, India, Mexico, the Russian Federation and the US (the median is approximately 45 per cent). 
Experience in these countries suggests a few guidelines for decentralisation. Firstly, in the case of developing countries, fiscal decentralisation is likely to generate imbalances at the subnational level which may lead to a deterioration of the fiscal position of the national/central government. As a result, the growth performance of these economies may be negatively affected. Secondly, mature federations and EU members have nevertheless experienced higher subnational spending shares for a much longer period than most developing countries mentioned, without significant fiscal imbalances at the centre. In these countries, more stringent control of subnational fiscal positions (applicable budget constraints with explicit transfers) seem to have prevented the deterioration of national and subnational fiscal positions owing to decentralisation.

Returning to Figure 1, most SADC members have centralised or unitary governments and are characterised in some cases by authoritarian rule and/or high military expenditures especially in war-torn countries such as the DRC. Several heads of state, for instance, those of Namibia and Uganda ${ }^{4}$ (with the most recent case in Zambia) have also opted to adjust their constitutions in order to lengthen their terms of office. Data are therefore not always available or nonexistent for subnational levels. Furthermore, in a number of countries decentralisation has not yet resulted in relinquished control from the centre and this is partly related to the quality of governance at different levels. Ghana, Malawi and Zambia have each created local councils, but the national government continues to direct almost all subnational spending and management decisions. Similarly, the ruling national party in Tanzania holds almost all subnational offices. Besides Uganda, South Africa is regarded as one of the few African countries that is in a process of unification through decentralisation.

South Africa is a much larger country than, say, France, Germany, the Netherlands and the UK combined, and compares well with these unitary countries in terms of revenue decentralisation. The share of subnational revenues remained relatively constant from 1990 to 2000 but increased to approximately 10 per cent. In comparison, a substantial change has occurred in terms of government expenditures and according to the new constitution (1994), the provinces have received many more responsibilities regarding expenditure. South Africa's national government therefore has a relatively small share in expenditures (about 50 per cent) in comparison with the European countries mentioned. This makes sense because the larger a country is, the more local governments it is bound to have. The provinces have a share of about 40 per cent of general government expenditure but relatively little own revenue, creating the need for a large amount of downward funding (unconditional and conditional or block grants). This will probably change in the future with the 
South African constitution making provision for a higher degree of devolution in terms of taxes. The process and methods of implementation (either through tax surcharges or tax sharing) is, however, still uncertain and future legislation should provide clarity on this issue.

From the discussions on fiscal decentralisation, it should be clear that decentralised fiscal systems offer a greater potential for improved macroeconomic governance, if managed correctly, than centralised fiscal systems. Mature federations in the developed world are proof of this conclusion. Decentralised fiscal systems require greater clarity in the roles of various players (centres of decision making) and transparency in rules that govern their interactions, to ensure fair play.

\section{COMMODITY TAXATION AND SOME OF THE IMPLICATIONS FOR TRADE}

Although in the short and medium term, the trade effects of the establishment of a free trade area (FTA) in Southern Africa are of particular importance for SADC members, more emphasis is placed on future issues concerning commodity taxation in the region. The liberalisation of regional trade will have definite fiscal effects with short-term loss of tax revenues, for instance those from SACU. Fiscal reform and specifically tax reform in this case, should therefore be initiated so that the already vulnerable macroeconomic position of SADC members is not exacerbated. Tax reform in this regard again entails the objectives of taxation. The distortionary influence of taxation on consumption (savings) and investment should be minimised (ensuring neutrality) whilst administrative costs should be kept as low as possible to ensure effectiveness.

The SADC technical arm spearheading trade negotiations, the Trade Negotiating Forum (TNF), has agreed on the various policies that are required to underpin the implementation of the Trade Protocol. It mainly recognises the need for harmonisation and also includes a need for macroeconomic stability. It also promotes the idea of a future common market set for after 2006. Various studies have been conducted on the introduction of the SADC FTA and its effects on Southern Africa (CREFSA, 1998; Evans, 1997; 1998 \& 2000; Akinkugbe, 2000; Roberts, 2000). The conflicting effects of other bilateral agreements on the SADC are included in these studies, for instance, the likely impact of the FTA between the EU and SA on the remaining member countries of the SADC which are neither party nor signatory to the agreements. At present, the other SADC-members belong to a wider regional grouping known as the African Caribbean and Pacific (ACP) group to which South Africa only holds qualified membership because it was not regarded as a typical less- 
developed country. South Africa was therefore excluded from any agreements between the EU and the ACP under the Lomé Convention.

In March 1996, the EU mandate of offers to South Africa for the FTA was formally tabled and negotiations commenced for the EU-SA FTA. Several rounds of negotiations were completed by the end of March 1999, giving rise to the Agreement on Trade, Development and Cooperation between the European Community and the Republic of South Africa of 1999. The agreement was finally signed on 11 October 1999 in Pretoria and the effective date of implementation fixed for 1 January 2000. The salient feature of the agreement is that the EU-SA FTA will be established over a transitional period, lasting on the South African side for a maximum of 12 years, and on the EU side for a maximum of 10 years from the date on which the agreements take effect. A phased elimination of duties is therefore designed in the agreements that will eventually lead to free movement of goods, services and capital between the EU and SA. The EU-SA FTA could therefore change the competitive advantage that the rest of the SADC members have and South African exports could even replace part of the other SADC members' current exports to the EU.

Akinkugbe (2000: 21) finds that "the implementation of the EU-SA FTA is almost parallel with that of the Uruguay Round negotiations (WTO agreements) around the world, in the sense that the competitive conditions of the SADC members vis-à-vis Europe stand to be fundamentally altered in the next decade or so". As already mentioned significant structural changes due to macroeconomic imbalances are thus necessary in those SADC economies planning to diversify the composition of their export trade. Furthermore, SACU members, particularly Swaziland and Lesotho, may lose a sizeable proportion of their annual fiscal revenue on the full implementation of the EU-SA FTA, and these countries will have to find other ways of diversifying their internal revenue bases rather relying on trade taxes. These effects are also similar to the full establishment of the SADC FTA and it is therefore realistic to think with the establishment of the SADC FTA with South Africa as one of the members, that the EU-SA FTA and the EU-ACP agreements will be incorporated into further integration measures to simplify the process.

\subsection{Trade within Southern Africa}

Observing the trade behaviour of the SADC members identifies some interesting characteristics. The SADC has successfully increased intra-regional trade over the past decade. The trade flows have increased more than tenfold since the formation of the SADCC. The SADC's performance has clearly outweighed that of other regional groupings within Africa, which reinforces the notion of the SADC being the most successful integration scheme in Africa 
(World bank, 2002). In 1997, the World Bank estimated intra-regional SADC exports to be over 11 per cent of total exports. However, many of the SADC members' major trading partners are still outside the community and the African continent. A significant share of the region's trade is conducted with the developed world and the EU in particular.

Over the past two decades, for instance, almost 40 per cent of all SADC exports were destined for Western Europe. There is also a strong correlation between trade patterns and their colonial ties. About 13 per cent of all SADC exports over the past two decades went to their former colonial rulers. Also, as already pointed out earlier in the discussion, trade levels are low because of the composition of their exports. They often find themselves dependent on the export of one single commodity. For instance, exports from Angola are predominantly oil (86 per cent) and for Botswana, diamonds (88 per cent), while Malawi's exports mainly comprise tobacco (76 per cent). It is also a wellknown fact that high dependence percentages make economies more vulnerable to fluctuations in price and therefore market conditions.

Table 2 South African trade within the SADC (excl. SACU), 1998-2001

\begin{tabular}{||l|r|r|r|r||}
\hline \multirow{2}{*}{ Country } & \multicolumn{2}{|c|}{$\begin{array}{c}\text { Percentage of total SA } \\
\text { exports }\end{array}$} & \multicolumn{2}{c||}{$\begin{array}{c}\text { Percentage of total SA } \\
\text { imports }\end{array}$} \\
\cline { 2 - 5 } & $\mathbf{1 9 9 8}$ & $\mathbf{2 0 0 1}$ & $\mathbf{1 9 9 8}$ & $\mathbf{2 0 0 1}$ \\
\hline Angola & 6,9 & 7,2 & 0,5 & 0,1 \\
\hline DRC & 6,4 & 3 & 0,8 & 0,6 \\
\hline Malawi & 7,7 & 7,6 & 21,3 & 10,9 \\
\hline Mauritius & 6,6 & 11,7 & 1,4 & 2,4 \\
\hline Mozambique & 16,9 & 24,9 & 10 & 12,3 \\
\hline Seychelles & 1,1 & 1,1 & 0,4 & 1,9 \\
\hline Tanzania & 6,6 & 6,6 & 1,3 & 1,3 \\
\hline Zambia & 13,5 & 21,1 & 9,9 & 7,7 \\
\hline Zimbabwe & 34,4 & 23,3 & 54,5 & 64 \\
\hline SADC & 11,1 & 11,8 & 11,1 & 11,2 \\
\hline \hline
\end{tabular}

Source: Department of Trade and Industry (2001)

Besides Western Europe, South Africa is the largest trading partner of other SADC members. Trade between South Africa and the rest of the SADC countries increased dramatically during the period 1990 to 2001 (see Table 2). Imports from the SADC increased from less than 1 per cent of total imports in 1990 to more than 11 per cent of total imports in 2001. The increase of South Africa's exports to the region was even greater - from 5 per cent of total exports in 1990 to almost 12 per cent of total exports in 2001. South African exports 
are concentrated in the value-added sectors such as minerals and base metals, chemicals, machinery, transport equipment and food and beverages.

The rapid increase in trade with SADC countries during the 1990s shows that South Africa enjoys a relative advantage in accessing these markets, mainly by virtue of its geographical proximity and South African businesspeoples' networks with their counterparts in the different SADC countries. The same, for instance, applies to Germany which enjoys a trade advantage in the EU towards neighbouring CEECs. Cross-border effects such as trade spillovers and cross-border shopping is therefore evident between South Africa and the other SADC members, rather than between the SADC members themselves.

South Africa experienced significant trade reforms and liberalisation because of its economic isolation prior to 1994. The import tariff rate (weighted average) declined significantly from 21 per cent in 1994 to 15 per cent in 1998. Textiles, electronic goods and automobiles are considered to be price elastic or sensitive and tariffs on these items will be phased out over the longer term. Trade liberalisation and change will continue in line with South Africa's commitment to the WTO (see NTSA, 2003). Since 1999, South Africa has concluded nonreciprocal bilateral trade agreements with Malawi, Mozambique, Tanzania, Zambia and Zimbabwe which should increase trade even further between South Africa and these countries. Under the EU-SA FTA, South Africa has also agreed to remove barriers on 86 per cent of EU imports, while the EU will scrap 95 per cent of its tariffs on South African goods phased in over a 12-year period.

At this stage, the average tariff rate in the countries of Southern Africa is about 12 per cent and this compares well with federations such as Argentina and Brazil (13,5 per cent). These rates are still uncompetitive compared with developed regions such as Japan (2,3 per cent) and the US (2,8 per cent) and Europe where the average is 2,7 per cent (WEF, 2003). South Africa has, however, established foreign trade relations but always attempts to improve on its trade performances by also improving small, micro and medium enterprises initiated though the Department of Trade and Industry's Ntsika project.

South African manufactured goods account for about 70 per cent of exports to Africa, where these goods have been successful because of competitive prices, shorter supply routes and a sound understanding of the African market. South Africa is, however, still largely reliant on the export of primary and intermediate commodities to developed countries despite attempts to diversify its export base. South Africa's principal exports are gold (40 per cent of total exports), platinum, diamonds, coal, food, wine and manufactured products. Imports mainly comprise capital goods, raw materials, semi-manufactured goods and 
consumer commodities, and originate primarily from Germany, Japan, the UK and the US. By February 2003, the main imports together with Switzerland and the BLNS countries, were machinery (30 per cent), chemicals (11 per cent) and minerals (8 per cent). Germany, Japan, the UK and the US are also major export markets for South Africa.

From the above-mentioned discussion, it should become clear that fiscal adjustment may not be as significant in South Africa as in other SADC countries where customs and import duties are still important in comparison with other revenue sources. Also, the notion that the integration among African states may be sub-optimal to the integration between African states and higherincome regions (e.g. the EU). Furthermore, "regional trade agreements between Sub-Saharan African (SSA) countries could be of limited value and could even lead to trade diversion and a divergence of per capita income amongst member states" (Naude \& Krugell, 2001: 502). This also means that for the SADC it would be more beneficial to integrate with the EU than with South Africa, and vice versa for South Africa. Further integration and fiscal adjustment measures should therefore rather be implemented as a cooperative mechanism between the members to ensure that tax revenues are equally distributed on some basis such as the population size.

\subsection{Commodity tax coordination and reform}

Figure 2 summarises the structure of the domestic tax systems of the federations and the SADC. For the SADC members there are still significant disparities. As already mentioned, Malawi, Mozambique, Zambia and Zimbabwe are countries that suffer the most from an FTA and/or customs union (Evans, 2000).

In general, tax systems are known to be non-neutral, that is, they cause distortions in terms of the allocation, especially in goods and factor markets in developing regions. Although estimates are unreliable, that is, the excess burden of taxation is significant in these countries various reforms have been introduced mainly to broadening the tax base with a simultaneous reduction in tax rates. In the SADC, members would either have to broaden the tax base or increase tax rates to compensate for losses incurred by the planned FTA and/or customs union. Some of these members have already started significant adjustments, especially in the field of commodity taxation, because capital income taxation does not allow much room to increase rates (see Fig 2) or broaden the base. Marginal income tax rates are already high in comparison with international standards and increases in these rates are likely to distort employment, savings and investment even more, with a likely increase in tax evasion. 


\section{Figure 2 Commodity tax revenue, 2000}

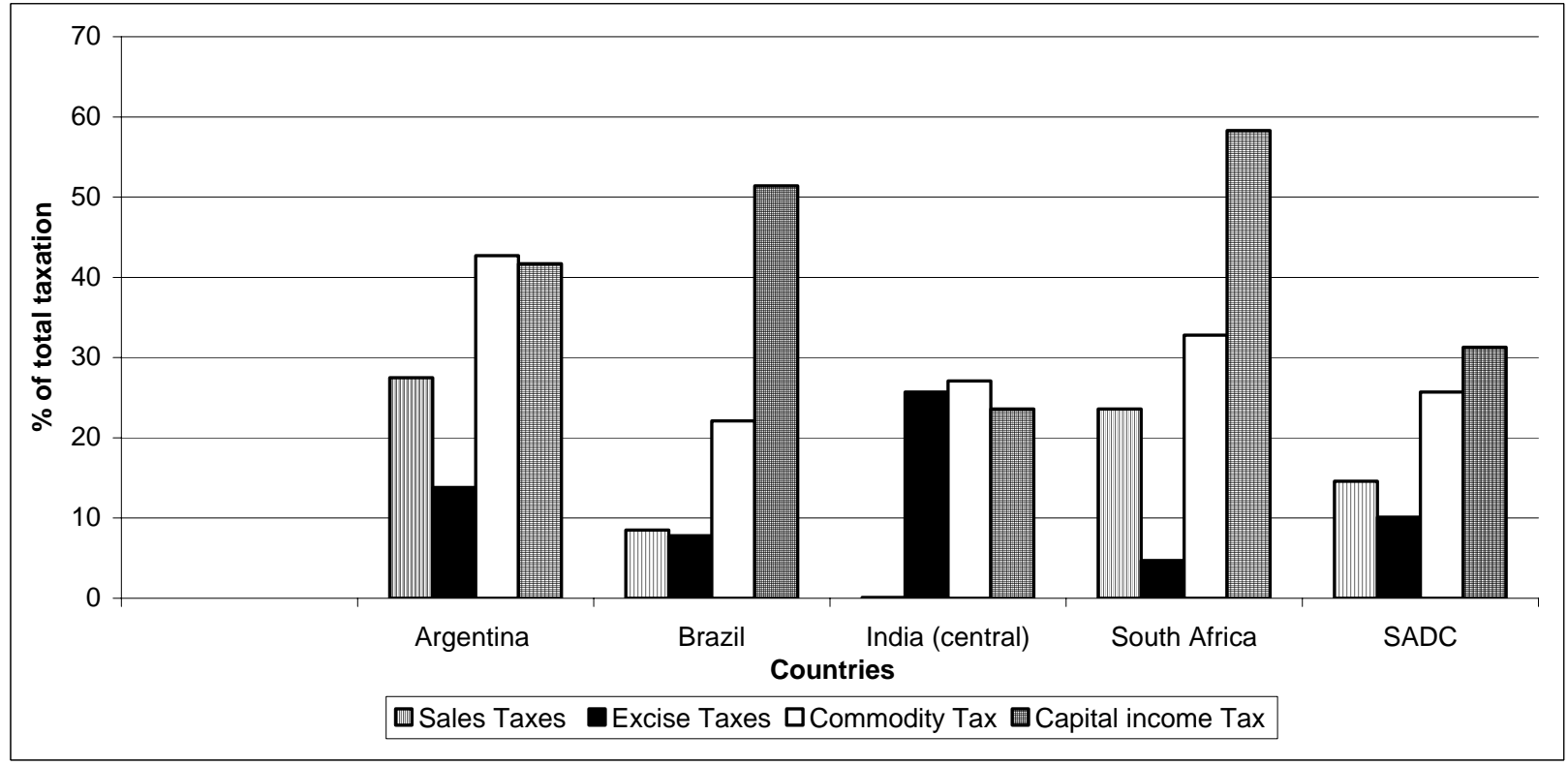

Source: IMF, 2002; See also Table A.2

In terms of the tax base, the average share of capital income taxes already carries a significant weight (31,3 per cent) and leaves some room for adjustment compared with the EU average (41,6 per cent). The worldwide tendency has, however, been to rather keep the corporate tax burden as low as possible in order to attract more active or fixed capital and even to zero-rate some withholding taxes on foreign interest income. The belief is that capital income taxes, specifically those on interest income, are "disappearing" because the implementation of the residence principle on interest income has become ultra burdensome with cooperation between governments not always forthcoming. The SADC member governments also realise the need for the attraction of capital and this can be observed from the numerous tax incentives provided in terms of export processing zones (EPZ) and foreign investors. Accepting that the SADC governments have already decided on the relevant balances between capital income and commodity taxation, the most significant reform measures and fiscal adjustment could occur in terms of commodity taxation in the SADC. Capital income taxation, however, is not flawless and there is room for improvement.

The average share of sales taxes (14,6 per cent) and excise taxes (10,1 per cent) in the SADC are still relatively low (Fig 2) compared with the EU average of 27,4 per cent for VAT and 18,9 per cent for excise duties. In terms of the federations, Argentina's subnational authorities' tax revenue as a share of total revenue is about 90,8 per cent, Brazil's 77,4 per cent and India's 83,4 per cent for 2000. Sales taxes (VAT) as a percentage of total taxation in Argentina are 27,5 per cent, Brazil 8,5 per cent and India only 0,1 per cent. The same shares 
in terms of excise taxation are 13,8 per cent in Argentina, 7,8 per cent in Brazil and 25,7 per cent in India. Although India's subnational share seems high, the central government still tends to undermine these authorities' rights and exercise to much control over these resources. The commodity tax shares of subnational levels are also much higher than those in mature federations such as Canada and the US.

Taxing powers have therefore been significantly devolved in Argentina, Brazil and India, and in some cases even to the detriment of the national governments. Although this trend of decentralisation is not observable within the SADC (only in South Africa), experiences from these countries can serve future prospects of SADC members as the region becomes more integrated towards a common market and possibly an economic union. The tax reform experiences of Latin American countries such as Argentina and Brazil, which have experienced significant tax reforms since 1980, can also provide important insights for future reform in the SADC. Latin American governments realised the importance of tax policy, and tax reform therefore became an integral part of wide-ranging economic reforms in the region.

Latin American governments found that tax policy was an instrument that was relatively easier to wield than politically difficult expenditure cuts, and its effects were more immediate, and in the short and medium term at least, it was more directly measurable than those of other economic policies. As Latin American economies became more integrated with the rest of the world, tax systems could no longer be viewed in isolation. The growth of emerging financial markets and the surge in direct investment and more open trade and payments regimes gave impetus to the reform movement. Tax competition became a prominent issue and governments realised that they had to reduce or eliminate taxes that raised business costs and domestic firms in positions where higher rates applied at a disadvantage in world markets.

At the beginning of the 1980s, most Latin American tax systems were complex and cumbersome, loaded with hundreds of revenue agencies with little revenue being collected. Consumption and production suffered because of multiple rates and were weakly administered (Shome, 1995). These taxes were also insufficient because of "cascading", which taxed not only the value of production but also taxes paid at earlier stages of production since they were generally levied at the manufacturing stage (such as those now present among some of the SADC members), rather than the retail stage, they hampered competition and added to production costs.

Tax reform in Latin America has been implemented in various ways. In Argentina, for instance, tax reform led to a radical redesign of the entire system, 
whereas in Columbia, it was carried out as a series of steps over a number of years. Reform-induced countries simplified their tax systems focusing on income taxation in the early years of the reform process and, increasingly, the taxation of production and consumption in later years. As the economies of the region matured and were integrated with the rest of the world, attention was also focused on the fine-tuning of particular aspects of the tax system with international ramifications such as the exchange of information, foreign tax credits and transfer pricing.

In terms of commodity taxation, VAT was an important part of the reform effort between the early 1980s and 1994, and the number of countries with a VAT doubled from 10 to 20 . In the early 1980s, some countries either had a rudimentary VAT up to the manufacturing-importing stage, or a productiontype (origin-based) VAT which disallowed credit for capital goods purchases. In the second half of the decade, these countries began to reform their VATs, by reducing the number of rates (Bolivia, Chile, Columbia and Mexico) and expanding the base by reducing exemptions and raising coverage, particularly of services (Argentina, Bolivia, Chile, Colombia and Mexico). Furthermore, some countries, notably Argentina, Chile, Colombia and Mexico converted to consumption-type (destination-based) VAT and improved their tax administrations.

Countries that achieved a large increase in their tax-to-GDP ratios, such as Argentina, Bolivia and Colombia often did so through VAT. As VAT revenue rose, countries relied less on excises, taxing only a few items such as beverages, tobacco, petroleum products and automobiles instead of a broad range of goods and services. All of the major countries in Latin America have also done away with export duties and most have reformed import tariffs with the dispersion of these rates being reduced and tariff levels significantly decreased. The Latin American experience is far from perfect, especially with regard to subnational commodity taxation as in Brazil. Fiscal or tax adjustments should therefore always directly be handled in line with economic circumstances in a particular country. As mentioned earlier, some SADC members have already started fiscal adjustments for the planned SADC free trade area (FTA) and/or customs union (CU), specifically in terms of commodity taxation. In the next section, commodity taxation in the SADC is discussed, specifically in terms of adjustment and reforms that might be needed in future.

\subsubsection{Fiscal adjustment and tax reform}

Table 3 gives an indication of the present commodity tax rates (column 2) against what is required in terms of the planned SADC FTA and/or future CU (column 3), and also excise tax categories. Namibia has experienced a 
significant adjustment with a switch from a GST of 8 per cent in 1997 to a standard VAT of 15 per cent with an increased rate of 30 per cent in 2000 (column 2, Table 3). This rate would leave ample room to compensate for any losses in terms of customs revenues. Tanzania also has a VAT system with a rate that changed from 10 to 20 per cent from 1997 to 2000, with the DRC close on its heels with a standard VAT rate of 18 per cent. Although these countries did not incur significant problems in compensating for any revenue losses of tariff reform, the rate is not as important as the quality of the reform involved. Keen and Lighthart (1999: 18) point out that, if an underlying tariff reform improves production efficiency, replacing the tariffs with domestic consumptions taxes (specifically emphasising VAT) will raise welfare in a small open economy. This should therefore also be applicable to those countries in which significant tariff reforms are necessary.

Countries such as Malawi, Mozambique, Zambia and Zimbabwe would lose the most in terms of the planned FTA and/or customs union (column 3, Table 3) and therefore require close scrutiny. Malawi has a so-called SUR-tax (between sales and value-added tax) of 20 per cent. CREFSA (1998) estimates that this rate would have to increase by 5 percentage points to offset revenue losses. Mozambique has a standard VAT of 17 per cent which was introduced in 1999 and as such is already on the road to change. Zambia has a standard VAT of 17.5 per cent introduced in 1995. According to CREFSA (1998), this rate would have to increase by 3 percentage points to offset losses. The VAT in Zimbabwe would have to change by 8 percentage points to 23 per cent if the present standard rate of 15 per cent on goods and services other than basic goods ( 0 per cent), electricity ( 5 per cent) and luxury goods and motor vehicles (25 per cent) is taken into account.

Mauritius, which has been relatively dependent on trade taxes, has a VAT of 15 per cent bringing it more in line with the rest of the SADC members. Besides rate increases, the mere fact of switching to VAT in the SADC can already improve the buoyancy of these revenue sources and decrease the distortions associated with commodity taxation.

Any sales tax that does not extend through the retail sales level can cause administrative problems because if the actual sales price is used, competitive distortions are created in different channels of distribution. For instance, when manufacturers or wholesalers sell directly to ultimate consumers at retail prices, the price should presumably be reduced to the wholesale level. However, if manufacturers sell directly to retailers who assume some manufacturing or wholesaling functions, the actual sales price should be increased to equalise the situation of such sales with those made through regular channels of distribution. This type of tax has, therefore, proven to be ineffective as a revenue-raising 
instrument in several countries such as Australia (see Messere, 1993), and countries such as Angola should also consider changing over to a VAT system. South Africa's experience probably served as a directive to those SADC countries that switched over to VAT during the 1990s and more recently.

Table 3 Commodity tax rates and excise categories, 2003

\begin{tabular}{|c|c|c|c|}
\hline Country & Sales tax rates (\%) & $\begin{array}{l}\text { VAT- } \\
\text { rates } \\
\text { (SADC } \\
\text { fta/cu) } \\
\end{array}$ & Excise categories \\
\hline Argentina $^{1}$ & $1-3.5$ (RST) & --- & $\begin{array}{l}\text { Wide variety (other than exports) at } \\
\text { varying rates. }\end{array}$ \\
\hline Brazil $^{1}$ & 7 \& 25 (ICMS) & --- & $\begin{array}{l}\text { Federal excise tax (IPI) which is } \\
\text { similar to a VAT. }\end{array}$ \\
\hline India $^{1}$ & $4(\mathrm{CST})$ & --- & $\begin{array}{l}\text { Levied on certain types of } \\
\text { manufactured goods. }\end{array}$ \\
\hline Angola & $\begin{array}{l}10 \& 30 \text { (sales tax at } \\
\text { manufacturing level) }\end{array}$ & N/A & $\begin{array}{l}\text { Other taxes include taxes on oil } \\
\text { production, an oil transaction tax } \\
\text { and a surface tax. }\end{array}$ \\
\hline Botswana & $\begin{array}{l}0 \& 10 \text { (sales tax at } \\
\text { manufacturing and } \\
\text { import level) }{ }^{2}\end{array}$ & 10 & $\begin{array}{l}\text { Tobacco (15 per cent), alcohol, fuel, } \\
\text { soft drinks and certain luxury goods } \\
\text { with specific rates on fuel and } \\
\text { alcohol. }\end{array}$ \\
\hline DRC & $\begin{array}{l}0.25-3 \text { (X), 3-13 (local), } \\
\mathbf{1 8} \text { (construction), } 30^{2}\end{array}$ & N/A & Luxury goods, alcohol and tobacco. \\
\hline Lesotho & $14^{2}$ & 11 & $\begin{array}{l}\text { Alcohol, fuel, soft drinks, matches } \\
\text { and certain luxury goods. Other } \\
\text { taxes include sand and stone levies } \\
\text { and a petrol levy. }\end{array}$ \\
\hline Malawi & 17.5 (SUR-tax) & 25 & Tobacco and alcohol. \\
\hline Mauritius & $15^{2}$ & 12 & $\begin{array}{l}\text { Tobacco, alcohol and materials } \\
\text { (textiles). }\end{array}$ \\
\hline $\begin{array}{l}\text { Mozam- } \\
\text { bique }\end{array}$ & $17^{2}$ & N/A & $\begin{array}{ll}\text { Tobacco, alcohol, } \\
\text { cosmetics and toiletries. }\end{array}$ \\
\hline Namibia & $15 \& 30$ (luxury goods) $^{2}$ & 15 & $\begin{array}{l}\text { Tobacco, alcohol, fuel, soft drinks } \\
\text { and certain luxury goods. Other } \\
\text { taxes include a sales duty ( } 0-25 \text { per } \\
\text { cent). }\end{array}$ \\
\hline Seychelles & $\begin{array}{l}\text { Trades tax under the } \\
\text { Trades Act } 1992 \text { on all } \\
\text { imports and locally } \\
\text { manufactured goods and } \\
\text { services. }\end{array}$ & N/A & --- \\
\hline
\end{tabular}




\section{Table 3 continued}

\begin{tabular}{||c|l|l|l||}
\hline \hline Country & Sales tax rates (\%) & $\begin{array}{l}\text { VAT- } \\
\text { rates } \\
\text { (SADC } \\
\text { fta/cu) }\end{array}$ & \multicolumn{1}{|c||}{ Excise categories } \\
\hline $\begin{array}{c}\text { South } \\
\text { Africa }\end{array}$ & $14^{2}$ & 14 & $\begin{array}{l}\text { Tobacco, alcohol, fuel, soft drinks } \\
\text { and certain luxury goods. Other } \\
\text { taxes include a fuel levy. }\end{array}$ \\
\hline Swaziland & $\mathbf{1 4} \& 25$ (luxuries) & 13 & $\begin{array}{l}\text { Imported local goods such as } \\
\text { tobacco, alcohol and petroleum } \\
\text { products. Other taxes include a } \\
\text { sugar cane levy, sugar export levy, } \\
\text { entertainment tax, sports levy and } \\
\text { fuel tax. }\end{array}$ \\
\hline Tanzania & $20^{2}$ & 11 & $\begin{array}{l}\text { Other taxes include a dairy industry } \\
\text { levy, entertainment tax and motor } \\
\text { vehicle registration tax. }\end{array}$ \\
\hline Zambia & $0 \& \mathbf{1 7 . 5}{ }^{2}$ & 20 & $\begin{array}{l}\text { Tobacco, alcohol, fuel and } \\
\text { entertainment tax. }\end{array}$ \\
\hline Zimbabwe & $0,5,10, \mathbf{1 5} \& 25$ & 23 & $\begin{array}{l}\text { Tobacco, alcohol, fuel, soft drinks, } \\
\text { petroleum products. Other taxes } \\
\text { include a tobacco levy and } \\
\text { automated financial transactions. }\end{array}$ \\
\hline
\end{tabular}

Notes: 1 In Argentina, a VAT of 21 per cent is applicable at federal level. Each of the 24 provinces imposes a quasi-RST (taxation on the gross revenue for the sale of goods and services) where most industries and exports are exempt from this tax. In India, the central government levies a VAT of 16 per cent (the Union excises). Besides the latter, a special tax, namely the central sales tax (CST) of 4 per cent, is levied by exporting states on interstate exports (origin-basis) in all the states and the revenues also accrue to the states. Brazil has a subnational VAT (7-25 per cent) levied on an origin-basis.

2 All these countries have a VAT system.

3 The BLNS countries and South Africa as SACU members maintain essentially the same tax base in terms of customs and excise duties (Customs and Excise Act with Amendments, 1964; NTSA, 2001). Source: PwC (2004)

The South African experience, like the experience of Latin American countries, can also provide useful lessons to the rest of the SADC members that are planning to switch over to a VAT system. The collection of commodity taxes through a comprehensive VAT (including retailers) has become standard practice worldwide. It has also become the focus of tax reform efforts in developing regions. In South Africa, the Margo Commission (1987: 345) 
recommended as an alternative to reducing the GST rate and introducing a comprehensive business tax (CBT) or a value-added income tax (VAIT), that GST should be abolished and replaced with a VAT credit or invoice-based system. Consequently, VAT was introduced on 30 September 1991.

\subsubsection{Base broadening and tax compliance}

In accordance with the OECD practice worldwide which is a reasonable indicator of "international best practice", VAT should be on a broad basis (including goods and services) and a credit (invoice) system, and the destination principle should hold. Thus far, the administrative ideal of only a few rates has been achieved in South Africa with only one standard rate and a zero rate. The rate has also been relatively low and increased from 10 to 14 per cent, which is still within the recommendation of the World Bank (1991) of between 10 and 20 per cent for developing countries. In 1996, the VAT base was broadened to include most fee-based financial services. However, the VAT system tends to be more regressive with a few exemptions and zero-ratings still in place. The Katz Commission (1994: 133) recommended against the further erosion of the VAT base through zero-rating or exemptions stating that targeted poverty relief and development programmes should rather receive priority instead. This currently is being done in South Africa through the Department of Public Works community-based projects. In addition, higher VAT rates on luxury goods or a multiple VAT rate system should be avoided. The main reason for the latter recommendation was that such a system would not reduce regressivity, would have high administration and compliance costs and would not have much additional revenue potential.

In a VAT credit system, multiple rates, as in the case of zero-rating (say, on exports) and exemptions, open up opportunities for fake claims and hence tax evasion, but also complicate administration for tax authorities and taxpayers alike. In the end, an optimal system of commodity taxation can be secured only if the loss of economic efficiency with VAT is minimised through uniform rates or a few rates applied to the broadest possible base. If this does not happen, a compromise will have to be made between administrative costs and equity. This case is even further strengthened if a system of income and expenditure supports is already in place for the poor.

A broad-base VAT also means that the necessary increase in tax rates is smaller than for specific commodity taxes such as excise taxes and that the risk of distorting specific markets is correspondingly lower. The SADC region can gain from South Africa's experience of excise duties. The World Bank (1991: 6) recommends setting three or four selective tax rates on luxuries and nonessentials, with the rate ascending according to the item's role in the 
consumption of the rich. The Katz Commission (1994: 133) recommends that the present ad valorem excise duties in South Africa be retained but that the possibility of introducing a progressive ad valorem duty on luxury motor vehicles should be investigated. Since 1994, excise taxes on tobacco products (for health reasons) have progressively been increased to 50 per cent of the retail price. The BLNS countries already have a common customs (which has been phased down in line with WTO regulations) and excise system applicable under South African legislation for SACU, and it will become necessary for a future SADC FTA (CU) to specifically coordinate excise duties for further integration purposes. The South African government has also initiated a rewrite of the Customs and Excise Act of 1964, primarily because its readmission to the international arena has shifted the focus from revenue collection to trade facilitation and control (NTSA, 2000: 73).

At present the excise categories in the SADC largely correspond and include mainly tobacco, alcohol, fuel, soft drinks and certain luxury goods (Table 3). The rates, however, still seem to differ considerably. In this regard, the EU experience can serve as an example with common customs and tariffs, and common excise duties, which have been set through minimum rates. The SADC countries should, however, be careful not to imitate developed regions' experience in every detail because as already mentioned, the needs of developing countries' may differ significantly from those of developed countries.

Another more recent experience of the Zambian government could better serve the SADC region. The government undertook a comprehensive review of both the tax system and customs duties, with the intention of significantly broadening the base of taxation. A considerable number of exemptions in both taxes and customs duties were eliminated and the emphasis shifted from specific consumption taxes such as excise duties to sales taxes in the form of VAT introduced during 1995. The Zambian authorities achieved higher revenues (tax revenue reached 31.5 per cent of the GDP in 2000), despite significant cuts in customs duties and marginal tax rates. The ultimate objective is that other SADC governments would learn from, say, the South African and Zambian experience. It is, however, questionable whether the different SADC governments cooperate with their neighbours or whether they have established links with one another ${ }^{5}$.

The Zambian experience reminds one of Argentina's experience with tax reform at the beginning 1990s. The government implemented radical changes in response to successive crises, and the lack of political resolve to enforce tax laws progressively eroded the tax structure and administration. Revenue only reached 11 per cent of the GDP in 1989, compared with 14 per cent in 1985. 
The strategy was thus to improve the quality and quantity of revenue mobilisation by eliminating taxes that were easy to collect but inhibited growth such as export taxes and taxes on financial transactions, and to concentrate instead on a few major taxes such as VAT and on overhauling the tax administration. The strategy was highly successful, and the ratio of tax revenue to GDP climbed to 16 per cent in 1993.

Argentina's VAT went from being the least revenue-productive ${ }^{6}$ in the world to being highly productive (Shome, 1995). The tax base was broadened and evasion sharply cut. Businesses failing to make timely or correct declarations were summarily closed for three days. In 1990, 700 taxpayers were penalised in this way. In 1992, the number rose to 12 000. This had a strong impact on VAT compliance. New invoicing requirements and controls were introduced, and expanded information on VAT taxpayers helped to improve the collection of other taxes by permitting tax inspectors to cross-reference tax data. Since the second half of 1992, the government has focused increasingly on using the tax system to improve enterprise competitiveness. Foreign trade taxes have been lowered and in an effort to improve the cost structure of the economy as a whole, the federal government has also started encouraging provincial governments to reduce or eliminate local taxes that impinge directly on enterprise costs. Although the Argentine VAT system is not flawless, it can teach the SADC an important lesson on the topics of base broadening and tax evasion.

Although it would appear unnecessary with a tax revenue effort already in full swing, a broadening of the tax base in the SADC could minimise upward pressure on tax rates, and thus improve the international competitiveness of the region and avoid excessive tax-induced distortions. It could also improve the revenue productivity of commodity taxes (GST and VAT), which is still relatively low measured in terms of OECD standards (CREFSA, 1998). Various countries also still maintain tax incentives concerning sales taxes on exports or export-processing zones (EPZs). For instance, in Angola, Malawi, Mauritius, Mozambique, South Africa, Zambia, and Zimbabwe all kinds of incentives (VAT exemptions, and customs and excise duty exemptions) on materials and inputs used for exporting purposes or within an export-processing zone (EPZ), are still included in the GST/VAT system. Although these incentives apply to outward-oriented operations, they can reduce the effective VAT rate and work against the objective of a broader and ultimately a coordinated base for the region as a whole. SADC governments have, however, increasingly started with concerted efforts in tax compliance, notably Mozambique where an independent UK-based private agency has been appointed to operate customs revenue, and in South Africa, where the South African Revenue Service (SARS), an autonomous agency within the public 
service, has been established. In both cases the result has been a significant increase in revenues collected.

Tanzania and Zambia have also established independent revenue authorities and it seems as if this type of reform appears to be gaining ground in the region with positive effects for revenue productivity. Zimbabwe had the same kind of spot calls in 1997 as those in Argentina in 1992. Under separate operations, the Department of Taxes and the Department of Customs and Excises in Zimbabwe checked businesses for tax payments and gained substantial sums of money outstanding. In South Africa, the SARS record speaks for itself. By the end of March 2001, SARS had continued its 6-year track record of surpassing tax collection targets (National Treasury of South Africa, 2001). Most of the additional revenue was derived from income tax and it would thus appear that tax evasion has been considerably reduced.

Although from experience, the most attractive instrument of commodity taxation for fiscal adjustment is a broad-based GST in terms of simpler administration and compliance, SADC members generally seem to be switching over to a destination-based VAT credit system. The administrative capacity of these countries seems to have a greater reliance on VAT, and this could even enlarge in future. Botswana, for example, has decided to introduce a destination-based VAT of 10 per cent in 2002, which will make its sales tax base much wider but with fewer exemptions and zero-rated exports. Lesotho, has also implemented a 14 per cent VAT on 1 July $2003^{7}$. The VAT system is usually known for its broad basis with value being added in each production stage (multiple stages). Higher rates are therefore more tolerable in terms of VAT rather than a US-type GST or RST levied at one stage. The VAT system normally entails more administrative costs and it is therefore important that the introduction of such a system involves careful planning and that governments already have the administrative capacity in place to maintain the system. An effective VAT system, if correctly implemented, can therefore eliminate any discrepancies that might exist in terms of bookkeeping for tax purposes and also tax evasion as such.

Shalizi and Squire (1988: 7) emphasise that if an "embryonic" or all-inclusive commodity tax is in place, the role of this taxation as a source of revenue should be expanded. In the short run, this could be achieved by means of an increase in the tax rate with a compensating reduction in tariff rates (as already pointed out in the case of the SADC). In the long run, expansion in the base will allow further reductions in rates and cause an increasing amount of revenue to be generated from the taxation of domestic activities. Further measures of fiscal adjustment in the SADC to reach the objective of regional growth may therefore include a broadening of the commodity tax base past the 
manufacturing/wholesales level as already discussed, and the broadening of capital income tax bases with enhanced compliance and disciplined spending.

\subsection{Future prospects}

It is clear from the investigation thus far that the SADC governments will have to make some adjustments in terms of commodity taxation and that there is always room for improvement. In this Section, future prospects in terms of the present system of commodity taxation that exist in the region will be explored. The possibility of the adoption of a VAT system for the whole of the region in particular will be analysed, especially with a view to further integration efforts such as a common market (CM). Under the present system, it would appear that most of the SADC governments will apply a destination-based VAT in the future, and that the intention in the short run could be to skip the FTA and immediately move to a CU where origin is irrelevant.

\subsubsection{Revenue sharing, revenue clearance and the destination principle}

The SADC might proceed with a CU because of the difficulty of compliance with origin rules in the planned FTA and/or CU. In a CU, countries are normally concerned with avoiding fiscal discrimination (i.e. ensuring tax neutrality) which causes differences in competitiveness, and the importance of fiscal autonomy or sovereignty is recognised. Customs duties are collected at the point of entry, irrespective of the final destination of the goods within the CU. All of the parties to the CU may therefore collect duties on imports destined for other parties. Unless the customs revenues from such cross-border or trans-jurisdictional imports are more or less equal, some mechanism or formula for revenue allocation must be devised if one of the parties is not to end up subsidising the other. For instance, in terms of SACU, BNLS imports from the rest of the world reach South African harbours first and South African imports alone are also much more than those of the BNLS countries. A CU therefore abolishes economic but not fiscal borders, and fiscal equalisation measures (e.g. the common revenue pool of SACU) are needed to eliminate distortions due to taxation.

In terms of the future SADC FTA/CU, countries such as South Africa may not be willing to provide compensatory mechanisms such as those applicable within SACU. The uncertainty exists about South Africa's ability or willingness to continue its compensation programme to current or any future members of an enlarged SACU (SADC) as well as the willingness of the other members to stay in SACU in the absence of such payments. As SACU continues to liberalise, the new revenue-sharing formula will become impractical but will also have a negative impact on smaller economies that have done little to diversify their 
revenue source. A similar problem arises in respect of other indirect taxes, especially the VAT, if the destination principle is to be upheld. It is often argued that this principle is rarely supported in full by tax-incidence analysis, and that if one considers the implications of the term "VAT" - a tax on value added in production - then its revenues should fall to the tax jurisdiction in which production (origin) takes place, rather than the one in which the final products are consumed (destination). The application of the destination principle, however, ensures that foreign sales (exports) are tax-exempt and all domestically paid taxes are reimbursed. Taxation therefore takes place in the importing country, including taxes on the last exchange with compensation corresponding to the various taxes that a similar product of the importing country would have paid in the preceding phases.

Normally special provisions such as border tax adjustments still have to be made to enable the exporter to be rebated for VAT previously paid in the importing country. The importer can then reclaim VAT after retail sale in the importing country. The destination-based VAT therefore guarantees a greater degree of neutrality and uniformity. For a future SADC CU/CM, revenue sharing or rebate schemes can be constructed on some general formula or on that of actual revenue clearance. Whereas the former has the advantage of administrative simplicity, it also raises questions of the formula's derivation and its adjustment over time. In the case of VAT, for instance, the general formula normally fails to take into account the composition of trade. For instance, it could be that VAT-exempt items constitute a larger share of Zimbabwe's exports to South Africa than of imports from South Africa. The formula would therefore overestimate the VAT revenue on South Africa's purchases accruing to Zimbabwe, thus underestimating the sum to be rebated to it from South Africa. More detailed formulas, on the other hand, would require frequent updating and renegotiation.

A bookkeeping approach or national accounts of revenue clearance on the basis of actual payments would make more sense for a future SADC. This will, however, require identification of the ultimate destination and that such information be readily available from a computerised customs-clearance system operated by the South African customs authorities which are now also responsible for customs and excises of SACU. In this case, it is important to add that the SADC Ministers of Finance signed a Memorandum of Understanding (MOU) on Cooperation in Taxation in 2002. The MOU will be incorporated into the SADC protocol on Trade and Investment that is due to be signed in 2004 (NTSA, 2003). Further, in terms of VAT, a credit system with invoices issued by the sellers (registered traders) to the importers will prevent double taxation. The importer normally uses this invoice to claim a rebate from his/her tax authorities for VAT already paid on inputs purchased from the 
exporting country and thus retrieving the money from the exporter's exchequer or revenue authorities.

In the absence of economic borders, say in a future SADC common market (CM), the difficulty of levying VAT on a destination basis (same as interest income on a residence basis) effectively means that the origin principle is practised. The origin principle is, however, distortive in terms of production. The destination principle (with a revenue-clearance system) will therefore make more sense in a developing context, specifically because production (exportoriented growth) and FDIs are first in line as employment generators. Furthermore, in a future SADC, competition could become exceptionally severe when tariffs have been eliminated among member countries in terms of a CM. Here, each country could promise a wider market to foreign capital than before and consensus would have to be reached in terms of tax diversity (competition) or uniformity. The same argument applies once revenue losses in terms of the SADC FTA have been recouped through, say, higher VAT rates, and countries such as Malawi, Zambia and Zimbabwe will have to re-evaluate their different situations to prevent tax competition from driving them out of the market. The experiences of other developing countries can also provide useful lessons in this context.

In countries such as India and Argentina, commodity tax reforms have proceeded more slowly (only started in 1992) than those in Brazil, perhaps because of fear of the same difficulties. India's sales tax system is still problematic because of its non-harmonised nature with various types of sales taxes at central and state level, including a CST levied on an origin basis at state level (Table 3). Most of the Asian economies carry a sales tax or VAT-rate of 10 per cent and as such the World Economic Forum (2003) classifies sales tax or VAT rates in Asian economies as a competitive asset whereas Latin America's sales tax or VAT systems is seen as a liability. Argentina, however, provides the best-case scenario in this analysis because it has already started to switch over to a destination-based subnational VAT system (Table 3).

Brazil's problematic VAT-system specifically, can therefore provide some interesting insights for the future decentralisation exercises of individual SADC members or for further integration of the SADC members (subnational level) into a common market or an economic union. Brazil was the first country to introduce a fully-fledged VAT in 1967. The introduction of VAT in Brazil and the consequent problems are directly related to the fact that it was also introduced as a subnational VAT. The rate structure also changed from a single to a multiple rate system and the new tax resulted in a series of complex technical and administrative problems of how to apply different VATs in the different states (the ICMS for each state) in addition to a federal VAT (the IPI) ${ }^{8}$. 
At present, the origin principle applies to interstate trade in Brazil. There is no meaningful concept of administrative integration between the federal and state versions of the VAT. Brazil therefore has the problems of dealing with crossborder trade which has been problematic even in the EU, but also excessive compliance and administrative costs, location distortion, and tax exporting and competition. Despite uniform rates for the states on exports and attempts to alleviate the distortionary effect of the origin principle by imposing a standard rate of 12 per cent on interstate trade (with an exception of a lower rate of 7 per cent on shipments to the poorer state), there are still economic complications.

Recent recommendations in Brazil made provision for the adoption of an integrated VAT system with a new federal ICMS that would be collected together with a revised state ICMS on the same base as a unified VAT at a uniform national rate consisting of a federal rate and a uniform state rate similar to the "harmonised" VAT system in Canada or the proposed "common" VAT system (1996) in the European Commission. After considerable debate, the state ICMS was substantially revised to eliminate significant elements of taxation on exports and investment in the existing system, with the federal government guaranteeing that no state would lose revenue as a result of the change. It is therefore argued that in Brazil, as in the case of Argentina and India, a decent VAT system with subnational governments also applying independent VATs will require the implementation of the destination principle at different tax rates on interstate trade and some means of compensating "losing" states for revenue losses implied by the transition. This type of system resembles the one in Canada, which is also similar to the CVAT option and also the tax-sharing option (specifically the so-called gewerbesteuer or local business tax) in Germany.

A good administrative system assisted by mutual trust and a high degree of negotiation between the different levels of government is necessary when the destination principle is applied. The theoretical case for the destination (residence principle) is strong but not absolute. The ease with which some commodities or capital goods can be moved means that a significant element of origin (source) taxation is always inescapable. However, consensus seems to exist in favour of maintaining as much of the destination principle as possible (maybe supporting it by use of restrictions on distance sales); also because of a fear of transfer pricing problems that potentially arise when VAT is levied by the origin principle ${ }^{9}$.

Although SADC governments' administrative capacities seem to have improved since the 1980s (Shalizi \& Squire, 1988), a high degree of mutual trust such as the one present in the "harmonised" VAT system of Canada or tax-sharing options of Germany, could still elude these governments ${ }^{10}$. The growing 
problem of direct sales through electronic commerce might still also become a problem in the SADC. The Green Paper on E-Commerce (RSA, 2000b: 30) in South Africa also recognises this problem and questions to what extent econsumption should be taxed. A consideration of alternative approaches (the CVAT and VIVAT systems) to the destination-based VAT system has therefore become necessary ${ }^{11}$.

When considering alternative approaches, the importance of an overarching authority again becomes clear. Keen (2000) argues that in the absence of an overarching authority, VAT systems run into difficulty in securing appropriate clearing, ensuring that revenue collected on exports from one jurisdiction is available to finance credits/refunds claimed in another. This problem could be resolved by providing incentives to subnational tax administrations to provide the appropriate level of effort in terms of their wider collective interests. Of course, also in terms of the EU where tax sovereignty is regarded as more important, the adoption of an overarching federal or supra-national authority becomes a natural outflow.

In the SADC the harmonisation or coordination of commodity taxation could become necessary in the long term. In the short term it is important to concentrate on revenue losses and therefore rate increases for some countries, notably Zambia and Zimbabwe. Cross-border trading has also shown significant growth with South African cross-border debtor finance worth approximately $\$ 20$ million in April $2001^{12}$. With enhanced cross-border trade the possibility of factor movements increases and the concept of tax competition in terms of customs and excise duties, sales taxes and VAT becomes relevant. In this regard, South African authorities would have to take the future effect of the enhanced taxing powers for South African provinces into account in terms of the whole SADC region. Intergovernmental relations will have to be coordinated in accordance with a strategy for the whole of the SADC.

The adoption of the destination principle is therefore advisable for a future SADC, although not always administratively feasible, and could secure most of the neutrality needed in a region that is in a process of trade liberalisation. With deeper integration and in the absence of border controls, a national accounts clearance mechanism operated by SARS or an agreed upon independent revenue authority, could be the sensible route to follow. Even if the destination principle prevails in the SADC, governments must consider the adoption of permissible tax rate "bands" for VATs although the benefits of complete harmonisation are unlikely to exceed the costs (CREFSA, 1998). A degree of flexibility could drive a "healthy", export-oriented competitive process with automatic harmonisation. 
Faria (1995: 24) summarises the experience of the EU with VAT as follows: "Within the EU, it has proved easier, in relation to VAT, to agree on the nature of the tax (consumption or destination type), and the base (virtually all domestic consumption goods and services except investment goods or financial services) than the tax rate structure (number and levels of rates, although the $6^{\text {th }}$ Directive has formalised a minimum rate level of 15 per cent)". Tax sovereignty (normally secured by the origin principle) will probably also be high on the agenda of SADC countries. Although a spontaneous harmonisation is possible with the adoption of proper convergence criteria as in the case of the EU, an overarching (independent) fiscal authority (and maybe a clearing mechanism in the absence of border controls) may be necessary for administrative ease and the perfection of VAT operation. This can only be achieved through a high degree of close cooperation and negotiation on the SADC governments' part, especially through Ministers of Finance. In short, developing countries such as those in the SADC have to choose a tax system that promotes growth and development.

Another factor that should never be overlooked in the choice of the most appropriate system of taxation in a future SADC is that a balance should be maintained between commodity and capital income taxation. It could happen that one country is in favour of high commodity taxation but not capital income taxation. The opposite could be true of another country within a future SADC, with the argument that low commodity taxation compensates for high capital income taxation. In the first case, the country with the high commodity taxation would favour the destination principle (with border tax adjustments). In the second, the country with the low commodity taxation would favour the origin principle because exports already carry a high capital income (corporate) tax burden.

\section{CONCLUSION AND RECOMMENDATIONS}

Most SADC members have centralised or unitary systems with some characterised by authoritarian rule and/or high military expenditures especially in war-torn countries such as Angola and the DRC. Several heads of state such as those of Namibia and Uganda, with the most recent case in Zambia, have also opted to adjust their constitutions in order to lengthen their terms of office. Data are therefore not always available or nonexistent for subnational levels. In a number of countries, decentralisation has not yet resulted in a relinquished control from the centre, and is partly related to the quality of governance at different levels. Besides Uganda, South Africa is regarded as one of the few African countries that are in a process of unification through decentralisation. The role of a democratic South Africa in terms of further regional integration (and thus the process of fiscal decentralisation) in Southern Africa therefore has 
to be confirmed.

Most SADC members will have to take action to restore internal balance, although countries such as Botswana, Lesotho, Mauritius, Namibia, Swaziland and Seychelles are already showing signs that further trade liberalisation will be to their advantage. Although countries such as Malawi, Mozambique, Zambia and Zimbabwe could lose in terms of revenue, broadened tax bases, improved tax compliance and rate increases of especially commodity taxes could significantly alleviate the problem. The importance of strong leadership should also be recognised, and in this regard it is advisable for the SADC to utilise South Africa's experience and resources to its advantage instead.

The South African economy is, an exception especially because of its relative size in the SADC. However, this should be regarded as an advantage in the region. The South African economy already makes significant contributions in terms of exports and imports in the region. It can therefore be expected that although compensation may be needed in the shorter term, a range of benefits from an expansion of foreign trade over the longer term would make the SADC economies less dependent on South Africa. A continuous process of trade liberalisation exercised with care could therefore be beneficial, although strategies such as tax competition (including profit-shifting) would have to be taken into account especially competition from other regions dominating trade in the developing world, for instance, Asia. This also includes effective commodity tax competition and/or coordination in a future SADC. Future studies could, therefore, model the behaviour of SADC countries in order to measure the degree of competition in terms of commodity taxation.

Issues emphasised and recommended include the following: (1) although not always administratively feasible, the destination principle can secure most of the neutrality needed in a region which is in a process of trade liberalisation; (2) directly linked to (1), the adoption of a national accounts clearance mechanism operated by SARS or an agreed upon independent revenue authority will be advisable with further integration; (3) governments could consider the adoption of permissible tax rate "bands" for VATs or minimum rates; although (d) a degree of flexibility (applied with care) could drive a "healthy" export-oriented competitive process with automatic harmonisation.

\section{ENDNOTES}

1 Argentina’s foreign debt soared to \$149,7 billion in 2001. 
2 This tax is levied at producer's level that is, a uniform tax is collected only on the output of domestic firms regardless of where this output is ultimately consumed. Exports are taxable whilst imports are zero-rated (production tax). Zero-rating implies that the firm files a return but pays zero tax on sales and gets a refund in respect of VAT payments made at earlier stages in the production and distribution chain. By contrast, exemption implies the firm need not file a VAT return and does not levy VAT but also cannot claim refunds for any VAT included.

3 The commodity tax is levied at the consumer's level and enables the region to collect a tax on all of its residents' private good consumption. If the destination principle is adopted in both the home and host regions, imports are taxed at the same rate as domestically produced goods and exports are zero-rated. As in the case of the residence principle, the destination principle is perceived to be a more fair and equitable practice because domestic and imported goods are treated the same (exports are zero-rated but imports are taxable). Administrative problems may be more likely with this system because of information difficulties in the taxation of imported goods.

4 Questions were also raised about the legitimacy of the elections in 2001 in which the current president, Mr Museveni, was re-elected with nearly 70 per cent of the votes.

5 In the event of directing various requests for information from the different SADC members, it was interesting to find that these countries do not have information about one another's tax systems and tax rates which indicates a lack of either cooperation or communication.

6 Revenue productivity of commodity taxes such as VAT/GST can be measured as follows: VAT/GST as per cent of GDP: VAT/GST tax rate.

7 In an electronic discussion with Mr GT Pasi, the Commissioner of Taxes from Zimbabwe, it was confirmed that Zimbabwe is also planning to switch over to a destination-based VAT.

8 Nowadays, Brazil levies a VAT payable on sales and transfers of goods (industry) in the form of a federal excise tax or then VAT (IPI or Imposto Sobre Productos Industrializados) at various rates in accordance with the nature of the product (10 to 15 per cent and in certain cases over 300 per cent). A state sales and services tax or VAT on agriculture, industry and other services (ICMS or Imposto Sobre Operacoes Relativas a Circulacao de Mercadirias e Servicios) of 7 to 25 per cent is also levied. In addition, a municipal services tax, the ISS (Imposto Sobre Servicios) is levied on gross income by municipalities on a variety of industrial, commercial, and professional services levied on gross income by municipalities on a variety of industrial, commercial and professional services.

9 Levying VAT on an origin basis effectively means charging the value 
that is added to a product in different jurisdictions at the rates charged by those jurisdictions. Multinational firms or firms operating in multiple jurisdictions then have an incentive to transfer price value-added into low-tax jurisdictions, say, charging high internal prices for intrafirm sales out of them.

10 In an electronic questionnaire to some of the SADC governments, one of the requests was whether they had any information about their neighbouring countries' tax systems. The answer was conclusively negative.

11 See Keen (2000) for an extensive discussion of alternative approaches to the destination-based VAT system such as the CVAT proposal for India and Brazil where an over-arching federal government exists and the viable integrated VAT or VIVAT proposal for the EU where no such authority exists.

12 International cross-border debtor finance was worth \$500 billion in 2000.

Acknowledgements: The author would like to thank the anonymous referees for useful comments. 


\section{APPENDIX A STATISTICAL TABLES}

Table A.1 Sub-national shares of selected federations and the EU

\begin{tabular}{||l|c|c|c|c||}
\hline \multirow{2}{*}{ Country } & \multicolumn{2}{|c|}{$\begin{array}{c}\text { Share of total government } \\
\text { expenditure (\%) }\end{array}$} & \multicolumn{2}{c||}{ Share of tax revenue (\%) } \\
\cline { 2 - 5 } & 1990 & $1997-2001$ & 1990 & $1997-2001$ \\
\hline Australia $^{1}$ & 50,4 & 49,7 & 20,7 & 25,1 \\
\hline Austria $^{1}$ & 31,9 & 32,2 & 21,7 & 20,7 \\
\hline Belgium $^{1}$ & 11,9 & 11,8 & 4,5 & 5,4 \\
\hline Canada $^{1}$ & 58,7 & 49,4 & 49,5 & 43,5 \\
\hline Denmark & 54,8 & 54,5 & 31,1 & 31,5 \\
\hline Finland & 46,5 & 41,2 & 25,9 & 27,6 \\
\hline France & 18,7 & 18,6 & 9,7 & 10,8 \\
\hline Germany & 40,2 & 37,8 & 28,9 & 28,8 \\
\hline Greece & --- & $7,9(1994)$ & --- & $3,6(1994)$ \\
\hline Ireland & 27,9 & 30,7 & 2,5 & 2,4 \\
\hline Italy & 22,8 & 25,4 & 3,6 & 6,5 \\
\hline Luxembourg & 19,9 & 16,9 & 6,8 & 6,3 \\
\hline The & 29,0 & 26,1 & 3,4 & 4,1 \\
Netherlands & & & & 5,9 \\
\hline Portugal & 8,7 & 11,6 & 3,6 & 13,8 \\
\hline Spain & 34,3 & 35,0 & 13,3 & 31,4 \\
\hline Sweden & 39,8 & 36,2 & 28,2 & 35,5 \\
\hline Switzerland & 51,2 & 49,3 & 37,0 & 3,6 \\
\hline UK & 29,0 & 27,0 & 5,9 & 32,9 \\
\hline US & 42,0 & 46,4 & 33,8 & \\
\hline
\end{tabular}

Note: These countries represent federations whilst the rest are EU members (including Austria, Belgium \& Germany)

Source: Own calculations - IMF (2002) 
Table A.2 Commodity tax revenue, 2002

\begin{tabular}{||l|c|c|c|c|c||}
\hline \multirow{2}{*}{ Country } & \multicolumn{2}{|c|}{$\begin{array}{c}\text { Commodity taxes } \\
\text { as \% of GDP }\end{array}$} & \multicolumn{2}{c|}{$\begin{array}{c}\text { Commodity taxes as } \\
\text { \% of total taxation }\end{array}$} & $\begin{array}{c}\text { Total } \\
\text { taxation } \\
\text { as\% of } \\
\text { GDP }\end{array}$ \\
\cline { 2 - 5 } & $\mathbf{A}^{1}$ & $\mathbf{B}^{1}$ & $\mathbf{A}$ & $\mathbf{B}$ & 12,5 \\
\hline Canada (provinces) & 2,7 & 1,6 & 21,2 & 12,5 & 5,6 \\
\hline US (states) $^{\text {Austria }}{ }^{2}$ & 1,9 & 0,9 & 33,3 & 16,0 & 33,4 \\
\hline Belgium & 6,0 & 2,7 & 27,2 & 12,2 & 33,2 \\
\hline Denmark & 1,3 & 3,2 & 8,1 & 19,8 & 35,3 \\
\hline Finland & 10,2 & 5,8 & 29,8 & 17,0 & 36,0 \\
\hline France & 8,6 & 5,4 & 35,4 & 22,2 & 40,1 \\
\hline Germany & 7,9 & 3,3 & 37,9 & 16,1 & 27,9 \\
\hline Greece & 3,4 & 3,2 & 30,1 & 28,0 & 40,3 \\
\hline Ireland & 9,4 & 6,6 & 33,7 & 23,5 & 33,0 \\
\hline Italy & 7,0 & 5,2 & 24,8 & 18,3 & 39,3 \\
\hline Luxembourg & 6,6 & 4,1 & 21,1 & 15,4 & 41,3 \\
\hline The Netherlands & 7,0 & 3,5 & 28,7 & 14,5 & 43,4 \\
\hline Portugal & 7,1 & 6,2 & 30,4 & 26,7 & 34,5 \\
\hline Spain & 4,9 & 2,9 & 28,7 & 16,7 & 41,3 \\
\hline Sweden & 7,0 & 4,4 & 29,7 & 18,8 & 33,4 \\
\hline UK & 6,4 & 4,7 & 23,2 & 17,2 & 34,2 \\
\hline EU 15 average & 6,6 & 4,4 & 27,4 & 18,9 & 36,4 \\
\hline \hline
\end{tabular}

Notes: 1 Commodity taxation includes categories $\mathrm{A}$ and $\mathrm{B}$, that is general taxes (including VAT) and taxes on specific goods and services (including excise taxes) respectively as defined by the OECD.

2 Starting with Austria, the EU members' commodity taxation is shown at central or national level.

3 Unweighted.

Source: OECD (2003) 


\section{REFERENCES}

1 BIRD, R.M. (1992) "Tax reform in Latin America: A review of some recent experiences”, Latin American Review, 27: 7-36.

2 CNOSSEN, S. (1998) "Reforming company taxation in Europe", in Sorenson, P.B. (ed.) Public Finance in a Changing World, MacMillan: London: 221-54.

3 COHEN, T. \& STEYN, G. (2001) "De Beers needs special meeting”, Business Day 24 April.

4 CREFSA, see Centre for Research into Economics and Finance in Southern Africa.

5 DE BONIS, V. (1997) "Regional Integration and commodity tax harmonization", World Bank Policy Research working paper 1848.

6 DE CROMBRUGGHE, A \& TULKENS, H. (1990) "On Pareto improving commodity tax changes under fiscal competition”, Journal of Public Economics, 41: 335-50.

7 DEPARTMENT OF TRADE AND INDUSTRY (2001) South African Trade Statistics (http://www.dti.gov.za).

8 EC, see European Communities Commission.

9 EUROPEAN COMMUNITIES COMMISSION (1987) Completing the internal market: The introduction of a VAT clearing mechanism for intraCommunity sales, EC: Brussels.

10 (1988) The Economics of 1992: An Assessment of the Potential Economic Effect of Completing the Internal Market in the European Community, EC: Brussels.

11 (1996) "A common system of VAT: A programme for the single market”, COM 96/328 final.

12 EVANS, H.D. (1997) "Study of the impact of the removal of tariffs of the free trade area of the Southern African development community (SADC)", Occasional Paper No. 5, Commonwealth Secretariat, Pretoria: SADC Industry and Trade Coordination Division (SITCD).

and results, Final Report, DTI and IDC: Pretoria.

14 (2000) Options for regional integration in Southern Africa, South African Journal of Economics, 68(4): 662-92.

15 FARIA, A.G.A. (1995) “Tax coordination and harmonization”, in Shome, P (ed.) Tax Policy Handbook, IMF: Washington D.C.

16 FEENBERG, D.R., MITRUSI, A.W. \& POTERBA, J.M. (1997) "Distributional effects of adopting a national retail sales tax", in Poterba, JM (ed.) Tax Policy and the Economy, Vol 11, MIT Press: Cambridge MA: 49-90.

17 FEHR, H., ROSENBERG, C. \& WIEGARD, W. (1995) Welfare Effects of Value Added Tax Harmonization in Europe, Springer: Berlin. 
18 FINANCIAL AND FISCAL COMMISSION, see South Africa (Republic).

19 FINANCE AND INVESTMENT SECTOR CO-ORDINATING UNIT (1999) (www.fiscu.gov.za).

20 FITZGERALD, J., QUINN, T., WHELAN, B. \& WILLIAMS, J. (1988) "An analysis of cross-border shopping”, Paper 137, The Economic and Social Research Institute: Dublin.

21 HAUFLER, A. (1993) Commodity Tax Harmonization in the European Community: A General Equilibrium Analysis of Tax Policy Options in the Internal Market, Physica-Verlag: Germany. (1998) "Asymmetric commodity tax competition: Comment on De Crombrugghe and Tulkens”, Journal of Public Economics 67: 135-44.

23 IMF, see International Monetary Fund.

24 INTERNATIONAL MONETARY FUND (2000) “Argentina: Selected issues and statistical annex”, IMF Staff Country Report No. 00/160, IMF: Washington D.C.

(2001) "Canada: Selected Issues”, IMF Staff Country Report No. 01/157, IMF: Washington D.C.

Washington D.C.

(2002) Government Finance Statistics Yearbook, IMF:

27 KATZ COMMISSION (1994) Interim Report of the Commission of Inquiry Into Certain Aspects of the Tax Structure of South Africa, Government Printer: Pretoria.

(1995) Third Interim Report of the Commission of Inquiry Into Certain Aspects of the Tax Structure of South Africa, Government Printer: Pretoria.

29 KEEN, M. (1987) "Welfare effects of commodity tax harmonization", Journal of Public Economics, 33: 107-14.

European Economic Review 33: 1-12.

(1989) "Pareto-improving indirect tax harmonization" (2000) "VIVAT, CVAT and all that: New forms of valueadded tax for federal systems", IMF Fiscal Affairs Department: Washington D.C.: 1-13.

32 KEEN, M. \& LIGTHART, J.E. (1999) "Coordinating tariff reduction and domestic tax reform”, IMF Working Paper WP/99/93, IMF: Washington D.C.

33 LEVINSOHN, J. \& SLEMROD, J. (1993) "Taxes, tariffs and the global corporation”, Journal of Public Economics, 51: 97-116.

34 LOCKWOOD, B. (1993) "Commodity tax competition under destination and origin principles”, Journal of Public Economics, 52: 141-62.

35 MARGO COMMISSION (1987) Report of the commission of inquiry into the tax structure of the Republic of South Africa, Pretoria: South Africa. 
36 McCCARTHY, C.L. (1999) "Polarised development in a SADC free trade area”, South African Journal of Economics, 67(4): 375-99.

37 THE MILLENIUM PARTNERSHIP FOR THE AFRICAN RECOVERY PROGRAMME (MAP) (2001) Government Printer: Pretoria.

38 MURPHY, R.L. \& MUSCOVITS, C. (1999) "Decentralisation, intergovernmental fiscal relations and macroeconomic governance: The Case of Argentina”, in Fukusaku, K \& de Mello, LR, Fiscal Decentralisation in Emerging Economies, Development Centre (OECD): Paris: 121-34.

39 NAUDE, W.A. \& KRUGELL, W. (2001) "Global integration of Africa versus regional integration in Africa", South African Journal of Economic and Management Sciences 4(3): 493-504.

40 NATIONAL TREASURY OF SOUTH AFRICA. (2000) The budget review, NTSA: Pretoria. (2001) The budget review, Pretoria: NTSA. (2003) The budget review, Pretoria: NTSA.

NTSA, see National Treasury of South Africa.

OMEGA PLAN (2001) Dakar: Senegal.

ORGANISATION FOR ECONOMIC COOPERATION AND DEVELOPMENT (1994) Tax information exchange between OECD member countries: A survey of current practices, OECD Publications: Paris. Paris: OECD Publications. (2003) OECD Revenue Statistics, Paris: OECD Publications.

8 PRICEWATERHOUSECOOPERS (PwC) (2004) Corporate Taxes 20032004. Worldwide Summaries, New York: John Wiley and Sons.

49 RSA, see SOUTH AFRICA (Republic)

50 SADC, see Southern African Development Community.

51 SARB, see South African Reserve Bank.

52 SHAH, A. (1999) "Fiscal federalism and macroeconomic governance: For better or for worse?” in Fukasaku, K. \& Mello, L.R. (eds.) Fiscal Decentralisation in Emerging Economies: Governance Issues, OECD Publications: Paris.

53 SHALIZI, Z. \& SQUIRE, L. (1988) “Tax policy in Sub-Saharan Africa”, Policy and Research Series No. 2, World Bank Publications: Washington D.C.

54 SOUTHERN AFRICAN DEVELOPMENT COMMUNITY 2001-2004. SADC member inputs, Telephonic and electronic interviews, April: Pretoria.

55 SOUTH AFRICA (Republic) (1996) The Financial and Fiscal Commission's Recommendations for the Allocation of Financial Resources to the National and Provincial Governments for the 1997/98 Financial Year (http//www.budget.gov.za). 
56 SOUTH AFRICA (Republic) (1997) The constitution of the Republic of South Africa, Wynberg: Hn Communications.

57 (Republic) (2000) Green Paper on E-Commerce: Making it your Business. Pretoria: Department of Communications.

58 SOUTH AFRICAN RESERVE BANK Quarterly Bulletin of the Reserve Bank, Various Issues.

59 STEIN, E. (1998) "Fiscal decentralisation and government size in Latin America”, in Fukasaku, K. \& Hausmann, R. (eds.) Democracy, Decentralisation and Deficits in Latin America, OECD Publications: Paris: 95-120.

60 TAIT, A.A. (1988) Value Added Tax, IMF: Washington D.C.

61 WORLD ECONOMIC FORUM (WEF) (2003) The Global Competitiveness Report: Switzerland.

62 ZEE, H.H. (1995) "Value added tax", in Shome, P (ed.) Tax Policy Handbook, IMF: Washington D.C. 